\title{
Vitamin D status of apparently healthy schoolgirls from two different socioeconomic strata in Delhi: relation to nutrition and lifestyle
}

\author{
Seema Puri ${ }^{1}$, Raman K. Marwaha ${ }^{2}$, Neha Agarwal ${ }^{1}$, Nikhil Tandon ${ }^{3}$, Rashmi Agarwal ${ }^{2}$, \\ Khushi Grewal $^{2}$, D. H. K. Reddy ${ }^{3}$ and Satveer Singh ${ }^{2}$ \\ ${ }^{1}$ Department of Foods and Nutrition, Institute of Home Economics, University of Delhi, New Delhi, India \\ ${ }^{2}$ Department of Endocrinology and Thyroid Research, Institute of Nuclear Medicine and Allied Sciences (INMAS), \\ New Delhi 110 054, India \\ ${ }^{3}$ Department of Endocrinology and Metabolism, All India Institute of Medical Sciences (AIIMS), New Delhi, India
}

(Received 8 April 2007 - Revised 23 July 2007 - Accepted 2 August 2007)

Forty to fifty per cent of skeletal mass, accumulated during childhood and adolescence, is influenced by sunlight exposure, physical activity, lifestyle, endocrine status, nutrition and gender. In view of scarce data on association of nutrition and lifestyle with hypovitaminosis D in Indian children and adolescents, an in-depth study on 3127 apparently healthy Delhi schoolgirls (6-18 years) from the lower (LSES, $n$ 1477) and upper socioeconomic strata (USES, $n$ 1650) was carried out. These girls were subjected to anthropometry and clinical examination for hypovitaminosis D. Girls randomly selected from the two strata (LSES, $n$ 193; USES, $n$ 211) underwent detailed lifestyle, dietary, biochemical and hormonal assessment. Clinical vitamin D deficiency was noted in $11.5 \%$ girls (12.4\% LSES, $10.7 \%$ USES). USES girls had significantly higher BMI than LSES counterparts. Prevalence of biochemical hypovitaminosis D (serum 25-hydroxyvitamin D $<50 \mathrm{nmol} / 1$ ) was seen in $90.8 \%$ of girls ( $89.6 \%$ LSES, $91.9 \%$ USES, NS). Mean intake of energy, protein, fat, Ca, vitamin D and milk/milk products was significantly higher in USES than LSES girls. Conversely, carbohydrate, fibre, phytate and cereal intakes were higher in LSES than USES girls. Physical activity and time spent outdoors was significantly higher in LSES girls $(92.8 v .64 \%, P=0.000)$. Significant correlation between serum 25 -hydroxyvitamin D and estimated sun exposure $(r 0 \cdot 185, P=0 \cdot 001)$ and percentage body surface area exposed $(r 0 \cdot 146, P=0.004)$ suggests that these lifestyle-related factors may contribute significantly to the vitamin D status of the apparently healthy schoolgirls. Hence, in the absence of vitamin $\mathrm{D}$ fortification of foods, diet alone appears to have an insignificant role.

Hypovitaminosis D: Schoolgirls: Nutrition: Lifestyle

Forty to fifty per cent of total skeletal mass at maturity is accumulated during childhood and adolescence. Many factors influence the accumulation of bone mineral during childhood like gender, heredity, endocrine status, nutrition, physical activity and sunlight exposure ${ }^{1}$. Evidence suggests that composition of the diet can play an important role in building and maintaining bone mass throughout life, primarily by providing bone-building nutrients. Diet cannot be isolated from other environmental factors, particularly in the instance of vitamin $\mathrm{D}$, which the body obtains from the action of sunlight on the skin as well as from the diet. The nutrients of importance to bone health are $\mathrm{Ca}, \mathrm{P}$ and vitamin $\mathrm{D}$. However, other dietary constituents such as protein, oxalates, phytates and fibre may also have an impact on bone health.

Evidence has emerged in recent years that vitamin D can no longer be thought of as a nutrient necessary for the prevention of rickets among children, rather it should be considered essential for overall health and well-being. Sub-optimal levels of vitamin D and decreased exposure to solar UV B radiation are associated with an elevated risk of a number of chronic diseases including malignancies, particularly of colon, breast and prostate gland, of chronic inflammatory and autoimmune diseases (e.g. type 1 diabetes mellitus, inflammatory bowel disease, multiple sclerosis), as well as of metabolic disorders ${ }^{2,3}$.

High prevalence of vitamin D insufficiency in healthy children and adolescents has been reported worldwide in the past few years ${ }^{4-9}$. However, data on vitamin $\mathrm{D}$ deficiency among Indian children and adolescents is scarce ${ }^{10}$. Pubertal age groups are more susceptible to vitamin D deficiency disorders. The onset of puberty often brings about a tremendous change in the lifestyle of young girls with restrictions imposed on their dress, outdoor activities etc. thus resulting in less sun exposure. Moreover, discrimination against the girl child is a well-documented fact in India. In many parts of the country intra-familial distribution of food shows significant male preferences. While there have been scattered epidemiological studies $^{11,12}$, few have investigated the contribution of nutritional factors to the prevalence of hypovitaminosis D in the population. This paucity of information has highlighted the need to investigate the association of nutrition and lifestyle with vitamin D status in healthy Indian girls. 
The present study was therefore planned to examine the role of lifestyle and diet on vitamin D status in healthy schoolgirls (6-18 years) from two different socioeconomic backgrounds in Delhi, India.

\section{Methods}

Subjects

The study design is presented in Fig. 1. The study was conducted in 3127 apparently healthy school girls $\left(6-18\right.$ years) from Delhi $\left(28.37^{\circ} \mathrm{N}, 77 \cdot 13^{\circ} \mathrm{E}\right)$, in the month of July. Socioeconomic stratification of the subjects was based on the type of school attended. Of the above 3127 girls, 1477 from government schools representing lower socioeconomic strata (LSES) and 1650 from private schools representing upper socioeconomic strata (USES) were randomly selected. The parents of each participant were informed about the study protocol and gave written informed consent approved by the institutional ethics committee of the Institute of Nuclear Medicine and Allied Sciences.

\section{Anthropometric and clinical profile}

Height was recorded without shoes, using a wall stadiometer to the nearest $1 \mathrm{~mm}$. Subjects were weighed using a clinical balance to the nearest $0.1 \mathrm{~kg}$, wearing light clothing and without shoes. BMI was calculated as weight (in $\mathrm{kg}$ )/height (in $\mathrm{m}^{2}$ ). Every morning, the scale and stadiometer were calibrated with standard weight and height, respectively. The BMI cutoffs provided by Cole et al. ${ }^{13}$ were used to classify children as normal, overweight or obese. Clinical vitamin D deficiency was diagnosed if a subject had either genu-varum or genu-valgum defined by intercondylar and intermalleolar distances $>6$ and $>8 \mathrm{~cm}$, respectively ${ }^{14}$.

Of this large cohort, a subgroup of 404 girls (193 LSES, 211 USES) selected by random cluster sampling from each class of the school underwent further laboratory, dietary and lifestyle assessment. Children with systemic illness, endocrine

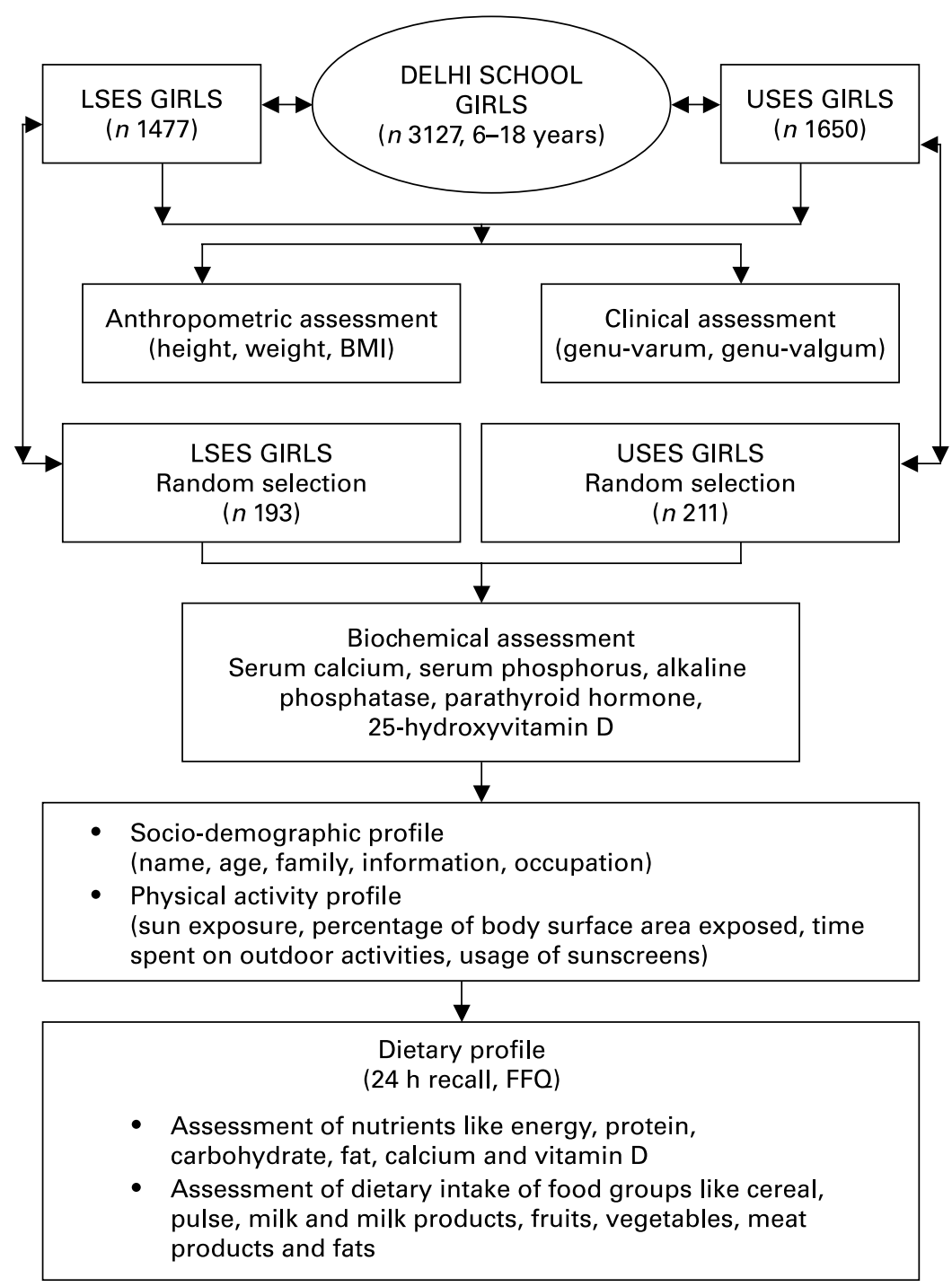

Fig. 1. Study design. LSES, lower socioeconomic strata; USES, upper socioeconomic strata. 
disorders and drugs affecting bone mineral health were excluded from the study.

\section{Biochemical profile}

Blood samples were collected from subjects in the fasting state at 08.00 hours without venostasis under basal conditions for estimation of serum $\mathrm{Ca}, \mathrm{P}$, alkaline phosphatase, 25-hydroxyvitamin D $(25(\mathrm{OH}) \mathrm{D})$ and immunoreactive parathyroid hormone (PTH). Serum was centrifuged at $4^{\circ} \mathrm{C}$ for $15 \mathrm{~min}$ at $1200 \mathrm{~g}$ and divided into five aliquots, which were refrigerated. Serum $\mathrm{Ca}, \mathrm{P}$ and alkaline phosphatase were estimated on the same day, and the remaining aliquots were stored at $-20^{\circ} \mathrm{C}$ until PTH and 25(OH)D were estimated. Serum Ca (Randox Laboratory Ltd, Crumlin, UK) and P (Clonital; Ampli Medical SPA, Milan, Italy) were measured by a colorimetric method and alkaline phosphatase by a liquid kinetic method (Clonital). The normal laboratory range for serum $\mathrm{Ca}$ is $2.02-2.60 \mathrm{mmol} / \mathrm{l}$ $(8.10-10.04 \mathrm{mg} / \mathrm{dl})$ and for serum $\mathrm{P}$ is $0.81-1.55 \mathrm{mmol} / \mathrm{l}$ $(2.5-4.8 \mathrm{mg} / \mathrm{dl})$, according to the kit manufacturers. The upper limit of serum $\mathrm{P}$ in mid-childhood is $1.87 \mathrm{mmol} / \mathrm{l}$ $(5.8 \mathrm{mg} / \mathrm{d} 1)^{15}$. The normal laboratory range for serum alkaline phosphatase at $37^{\circ} \mathrm{C}$ is $100-275 \mathrm{IU} / 1$ in adults and $180-1200 \mathrm{IU} / 1$ in children before epiphyseal closure.

The serum concentration of $25(\mathrm{OH}) \mathrm{D}$ (reference range $22.4-93.6 \mathrm{nmol} / \mathrm{l}(9.0-37.6 \mathrm{ng} / \mathrm{ml}))$ and immunoreactive PTH (reference range $13-66 \mathrm{pg} / \mathrm{ml}$ ) were measured by RIA and immunoradiometric assay (Diasorin, Stillwater, MN, USA), respectively. The definition of hypovitaminosis D was based on two criteria: firstly, serum concentration of $25(\mathrm{OH}) \mathrm{D}$ below $50 \mathrm{nmol} / 1(20 \mathrm{ng} / \mathrm{ml})$ and, secondly, as recommended by $\operatorname{Lips}^{16}$, as mild $(25-50 \mathrm{nmol} / \mathrm{l})$, moderate $(12.5-25 \mathrm{nmol} / \mathrm{l})$ and severe hypovitaminosis $\mathrm{D}(<12.5 \mathrm{nmol} / \mathrm{l})$.

\section{Dietary profile}

The dietary information was collected using well-established tools: $24 \mathrm{~h}$ dietary recall, FFQ and using the interview technique.

The $24 \mathrm{~h}$ dietary recall provided detailed quantitative information regarding the foods consumed over the previous $24 \mathrm{~h}$ in terms of household measures. Using standardized recipes of the food preparations ${ }^{17}$, the daily intake of various food groups (cereals, pulses, fruits, vegetables, milk, meat products and fat) was determined. Based on the amount of foods consumed in a day, the dietary intake of nutrients (energy, protein, carbohydrate, total fat, dietary fibre, phytate, $\mathrm{Ca}$ and $\mathrm{P}$ ) was calculated using Nutritive Value of Indian Foods ${ }^{18}$ and was compared with Nutrient Requirements and Recommended Dietary Allowances for Indians ${ }^{19}$ for all nutrients except vitamin D. Since no dietary estimates of vitamin $\mathrm{D}$ are provided in published Indian food tables, the calculations for vitamin D intake are based on US Department of Agriculture provisional tables on the vitamin $\mathrm{D}$ content of foods ${ }^{20}$.

The FFQ was used to elicit retrospective qualitative information regarding the frequency of consumption of various foods. Over ninety-five food items were listed from all the food groups. These tools have been used in our earlier research work $^{21}$. In the present investigation these tools were pre-tested on twenty girls before finalization and administration.

\section{Lifestyle profile}

A self-designed structured interview schedule cum questionnaire was prepared by the investigator to elicit information regarding family background, living conditions, style of dress, direct sunlight exposure, parts of the body exposed daily, time spent outdoors during the school day and on weekends, time spent on exercising and play (indoor or outdoor) and sunscreen usage. Direct sunlight exposure was assessed by documenting average duration of exposure and percentage of the surface area of the body exposed daily $^{22}$. The ground surface of Delhi received a mean of 2 Minimum Erythemal Dose per hour (MED/h) of UV B radiation $(290-320 \mathrm{~nm})$ during the study period (Meteorology Department, Delhi).

In the present investigation these tools were pre-tested on twenty girls before finalization and administration.

\section{Statistical analysis}

The data were analysed by SPSS statistical software (version 11.0; SPSS Inc., Chicago, IL, USA). Descriptive statistics are expressed as means and standard deviations. Independent sample $t$-test (two-tailed) was used to compare differences between the two socioeconomic groups for continuous variables. $\chi^{2}$ test was performed for categorical variables. Pearson's correlations were used to assess the association between variables.

\section{Results}

\section{Clinical characteristics}

Data were analysed separately for the two socioeconomic groups and appropriate comparisons made. USES subjects had significantly higher mean height (145.7 (SD 15.72) $v$. 141.3 (SD 13.4) cm, $P=0.013$ ), weight (38.75 (SD 15.37) v. 34.9 (SD 10.8) kg, $P=0.000)$ and BMI (18.89 (SD 5.02) v. $\left.17 \cdot 0(\mathrm{SD} 3 \cdot 1) \mathrm{kg} / \mathrm{m}^{2}, P=0 \cdot 000\right)$ than LSES subjects across all ages. High prevalence of overweight (21.5 v. $4.4 \%$, $P=0.000)$ and obesity $(5.2$ v. $0.6 \%, P=0.021)$ was seen in USES as compared to LSES subjects; as per Cole et al. cutoffs $^{11}$. Clinical evidence of vitamin D deficiency was noted in $11.5 \%$ of subjects ( $12.4 \%$ LSES, $10.7 \%$ USES, $P=0.68$, NS). Prevalence of genu-valgum was $5.2 \%$ and genu-varum was $6.4 \%$ in the total cohort.

\section{Physical, biochemical and lifestyle parameters of the subgroup}

The age, physical characteristics and biochemical parameters of the subgroup of 404 (193 LSES, 211 USES) randomly selected subjects is shown in Table 1 . There is no difference in the mean age between the groups. The height, weight and BMI of USES subjects were significantly higher than LSES. High prevalence of overweight and obesity is seen in USES subjects supported by strong correlations between energy intake and BMI $(r 0.368, P=0.000)$ and energy and fat intakes $(r 0.575, P=0 \cdot 000)$.

Subjects in USES group had significantly higher mean serum $\mathrm{Ca}$ and significantly lower mean serum alkaline phosphatase and $25(\mathrm{OH}) \mathrm{D}$ levels. A value of $25(\mathrm{OH}) \mathrm{D}$ less than 
Table 1. Baseline characteristics, lifestyle and biochemical parameters of the cohort

(Mean values and standard deviations)

\begin{tabular}{|c|c|c|c|c|c|c|c|}
\hline \multirow[b]{2}{*}{ Variables } & \multicolumn{2}{|c|}{ LSES ( $n$ 193) } & \multicolumn{2}{|c|}{ USES (n 211) } & \multirow[b]{2}{*}{$P$ value $^{*}$} & \multicolumn{2}{|c|}{ Entire cohort ( $n$ 404) } \\
\hline & Mean & SD & Mean & SD & & Mean & SD \\
\hline Age (years) & $12 \cdot 4$ & $3 \cdot 2$ & $12 \cdot 3$ & $3 \cdot 0$ & 0.704 & $12 \cdot 3$ & $3 \cdot 1$ \\
\hline Height $(\mathrm{cm})$ & $140 \cdot 3$ & $14 \cdot 3$ & $146 \cdot 9$ & $14 \cdot 0$ & 0.000 & 143.7 & 14.5 \\
\hline Weight (kg) & 33.9 & $10 \cdot 7$ & 41.5 & $13 \cdot 0$ & 0.000 & $37 \cdot 8$ & $12 \cdot 5$ \\
\hline BMI $\left(\mathrm{kg} / \mathrm{m}^{2}\right)$ & $16 \cdot 7$ & 2.9 & $18 \cdot 7$ & 3.5 & 0.000 & $17 \cdot 7$ & 3.4 \\
\hline Serum Ca $(\mathrm{mmol} / \mathrm{l})$ & $2 \cdot 22$ & 0.2 & $2 \cdot 30$ & 0.1 & 0.000 & $2 \cdot 27$ & 0.17 \\
\hline ALP (IU/I) & 484.5 & 257.5 & 330.6 & $170 \cdot 3$ & 0.000 & $404 \cdot 1$ & $229 \cdot 4$ \\
\hline PTH (pg/ml) & $32 \cdot 4$ & $20 \cdot 8$ & 33.4 & $19 \cdot 7$ & 0.615 & 32.9 & $20 \cdot 2$ \\
\hline $25(\mathrm{OH}) \mathrm{D}(\mathrm{nmol} / \mathrm{l})$ & 34.61 & $17 \cdot 43$ & $29 \cdot 38$ & $12 \cdot 69$ & 0.001 & 31.87 & $15 \cdot 43$ \\
\hline Daily sun exposure (min) & 45 & & 25 & & 0.003 & 35 & \\
\hline Body surface area exposed (\%) & 28 & & 15 & & 0.014 & $21 \cdot 5$ & \\
\hline Sunscreen application (\%) & 0 & & 28 & & 0.000 & - & \\
\hline
\end{tabular}

ALP, alkaline phosphatase; LSES, lower socioeconomic strata; 25(OH)D, 25-hydroxyvitamin D; PTH, parathyroid hormone; USES, upper socioeconomic strata.

${ }^{*}$ As tested by independent sample $t$-test (two-tailed) of the difference between the means of LSES and USES subjects.

$22.4 \mathrm{nmol} / \mathrm{l}(9 \mathrm{ng} / \mathrm{ml})$ was noted in 121 out of 404 , i.e. $29.9 \%$ of subjects $(25.4 \%$ LSES, $34 \cdot 1 \%$ USES, $P=0 \cdot 072)$. However, only $14.8 \%$ had elevated PTH levels $(>66 \mathrm{pg} / \mathrm{ml})$. As per Lips classification, hypovitaminosis D $(<50 \mathrm{nmol} / \mathrm{l})$ was seen in $90.8 \%$ of the population, $89.6 \%$ LSES $(5.2 \%$ severe, $25.4 \%$ moderate, $59 \%$ mild) and $91.9 \%$ USES ( $2.8 \%$ severe, $36.5 \%$ moderate, $52.6 \%$ mild), the difference being non-significant. A significant negative correlation between the mean serum PTH and 25(OH)D $(r-0.14$, $P=0.005)$ and $25(\mathrm{OH}) \mathrm{D}$ and BMI $(r-0.170, P=0 \cdot 001)$ was noted. Although mean serum $\mathrm{Ca}$ was within the normal range for both the groups, prevalence of sub-clinical $\mathrm{Ca}$ deficiency (i.e. serum $\mathrm{Ca}<2.02 \mathrm{mmol} / \mathrm{l}$ ) was significantly higher in the LSES group (15 v. $0.47 \%, P=0.000$ as tested by $\chi^{2}$ ).

The girls in the LSES school had significantly higher sun exposure than did those attending the USES school (Table 1). Girls from both the schools followed a dress code of half-covered arms and fully covered legs. Time spent on outdoor activities which include exercising, play, walking to tuitions and other household chores was higher in LSES subjects (LSES $=41.5 \quad(\mathrm{SD} 26.0) \mathrm{min} / \mathrm{d}$, USES $=36.3(\mathrm{SD} \mathrm{16.2}) \mathrm{min} / \mathrm{d}, P=0.018)$. A significantly higher percentage of LSES girls $(92.8 v .64 \%, P=0.000)$ were involved in various outdoor activities as tested by $\chi^{2}$. A significant correlation was found between serum $25(\mathrm{OH}) \mathrm{D}$ concentration and estimated sun exposure ( $r 0 \cdot 185, P=0 \cdot 001$ ), and between $25(\mathrm{OH}) \mathrm{D}$ and percentage of body surface area exposed $(r 0 \cdot 146, P=0.004)$.

\section{Dietary profile}

Table 2 presents the mean daily food and nutrient intake by the girls from two strata. Both the groups, LSES and USES, consumed predominantly vegetarian diets, i.e. $55.7 \%$ of the subjects were vegetarian $(58.9$ v. $52.6 \%, P=0.198), 9.7 \%$ 'eggetarian' (9.5 v. $10 \%, P=0.88)$ and only $34.5 \%$ were non-vegetarian (31.6 v. $37.4 \%, P=0.22)$. Although the USES group had a higher percentage of non-vegetarians, the frequency of consumption of non-vegetarian dishes was only once a week. Fish was a rare diet item in both the groups.
USES had significantly higher consumption of pulses, milk, animal foods, fruits and fat in their daily diets as compared to LSES girls where cereals formed the major constituent; nevertheless both the groups had daily intakes less than the Indian Council of Medical Research recommendations ${ }^{19}$. A trend of significantly lower energy, protein, fat and $\mathrm{Ca}$ intakes in LSES as compared to USES was seen across all ages. Mean energy intakes were 65 and $70 \%$ lower than the RDA in LSES and USES subjects, respectively. Predictably, the protein intakes showed a linear trend with respect to age of the students. Higher protein intake of USES corroborated with significantly increased intake of milk, milk products $(P=0.000)$ and animal foods $(P=0 \cdot 000)$. A daily fat intake contributing to $\geq 30 \%$ of energy intake was observed in $67 \%$ of USES subjects leading to high prevalence of overweight and obesity.

The mean intake of dietary $\mathrm{Ca}$ (dairy $\mathrm{Ca}+$ non-dairy sources) was significantly lower in LSES subjects whereas the mean $\mathrm{Ca}$ intakes of USES girls was significantly greater than the RDA matched for all age groups (Table 2). The major source of dietary $\mathrm{Ca}$ in the USES diets was milk and its products (i.e. dairy foods). It was observed that $85.6 \%$ of USES girls consumed milk daily or frequently in comparison to only $37.4 \%$ of LSES subjects. The consumption of milk products like curd, cheese, cottage cheese and milk-based desserts was influenced by social class with the USES subjects reporting more frequent consumption of milk-based desserts like ice cream, custard, rice pudding and traditional sweets (mithai). Ice creams were a favourite item amongst both the groups but the LSES group consumed mainly ice candies whereas the USES subjects preferred milk-based ice creams. A significant negative correlation was seen between dairy $\mathrm{Ca}$ and phytate $(r-0 \cdot 219, P=0 \cdot 000)$ and between dairy CA and fibre $(r-0 \cdot 253, P=0 \cdot 000)$, indicating an inverse relationship between dairy foods and cereal consumption.

LSES diets had a significantly higher content of cereals as shown in Table 1, making the diets rich in carbohydrate, phytate and fibre. A negative correlation between serum $\mathrm{Ca}$ and phytate $(r-0.067, P=0.177)$ and serum $\mathrm{Ca}$ and fibre $(r-0.065, P=0.185)$ was seen. The daily intake of vitamin D-containing foods like milk, egg yolk, meat and butter 
Table 2. Intake of food groups and nutrients of the cohort

(Mean values and standard deviations)

\begin{tabular}{|c|c|c|c|c|c|c|c|c|}
\hline \multirow[b]{2}{*}{ Diet variables } & \multirow[b]{2}{*}{ SI/RDA } & \multicolumn{2}{|c|}{ LSES ( $n$ 193) } & \multicolumn{2}{|c|}{ USES ( $n$ 211) } & \multirow[b]{2}{*}{$P$ value $^{*}$} & \multicolumn{2}{|c|}{ Entire cohort ( $n$ 404) } \\
\hline & & Mean & SD & Mean & SD & & Mean & SD \\
\hline \multicolumn{9}{|l|}{ Food groups } \\
\hline Cereals $(g / d)$ & $210-300$ & 203.4 & 44.6 & 158.8 & 42.5 & 0.000 & $180 \cdot 1$ & $48 \cdot 8$ \\
\hline Pulses (g/d) & $45-60$ & 34.9 & $21 \cdot 9$ & 40.1 & $24 \cdot 0$ & $0 \cdot 101$ & $37 \cdot 6$ & $23 \cdot 1$ \\
\hline Vegetables $(\mathrm{g} / \mathrm{d})$ & 300 & $80 \cdot 2$ & $47 \cdot 3$ & 114.4 & $52 \cdot 8$ & 0.000 & $98 \cdot 1$ & 53.0 \\
\hline Fruits $(g / d)$ & 100 & 32.8 & $46 \cdot 7$ & 91.4 & 78.1 & 0.000 & 63.5 & $71 \cdot 1$ \\
\hline Milk (g/d) & 500 & 211.4 & $132 \cdot 7$ & $362 \cdot 7$ & 141.4 & 0.000 & $290 \cdot 4$ & $156 \cdot 6$ \\
\hline Animal foods $(\mathrm{g} / \mathrm{d})$ & 100 & $3 \cdot 3$ & $11 \cdot 8$ & 13.3 & $27 \cdot 3$ & 0.000 & $8 \cdot 6$ & 21.9 \\
\hline Fats $(\mathrm{g} / \mathrm{d})$ & 25 & $23 \cdot 2$ & $6 \cdot 6$ & $24 \cdot 3$ & 6.6 & 0.022 & $23 \cdot 8$ & $6 \cdot 6$ \\
\hline \multicolumn{9}{|l|}{ Nutrients } \\
\hline Energy (kJ) & $8151-8611$ & $5542 \cdot 3$ & $716 \cdot 4$ & $5849 \cdot 1$ & $677 \cdot 1$ & 0.000 & $5702 \cdot 4$ & $712 \cdot 3$ \\
\hline Protein (g) & $41-65$ & 37.4 & $7 \cdot 0$ & 43.8 & $7 \cdot 1$ & 0.000 & $40 \cdot 8$ & $7 \cdot 8$ \\
\hline Protein (\% of energy) & & $11 \cdot 0$ & & $12 \cdot 5$ & & & & \\
\hline $\mathrm{CHO}(\mathrm{g})$ & - & $202 \cdot 8$ & $31 \cdot 6$ & 194.6 & $30 \cdot 2$ & 0.009 & 198.5 & $31 \cdot 1$ \\
\hline $\mathrm{CHO}$ (\% of energy) & & 60.4 & & 55.5 & & & & \\
\hline Fat $(g)$ & 22 & 39.5 & $7 \cdot 7$ & $49 \cdot 2$ & $7 \cdot 4$ & 0.000 & 44.6 & 8.9 \\
\hline Fat (\% of energy) & & $27 \cdot 4$ & & $32 \cdot 0$ & & & & \\
\hline Dietary fibre $(\mathrm{g})$ & - & 13.9 & 7.5 & 9.7 & $6 \cdot 2$ & 0.000 & $11 \cdot 7$ & $7 \cdot 2$ \\
\hline Phytate (mg) & & $105 \cdot 3$ & $53 \cdot 3$ & 85.6 & 53.6 & 0.000 & $95 \cdot 0$ & $54 \cdot 3$ \\
\hline $\mathrm{Ca}(\mathrm{mg})$ & $400-600$ & 454.2 & 187.4 & 685.5 & 184.8 & 0.000 & $575 \cdot 0$ & $218 \cdot 9$ \\
\hline Dairy Ca (mg) & & 253.6 & 159.2 & 435.3 & $169 \cdot 6$ & 0.000 & 348.5 & 187.9 \\
\hline Non-dairy $\mathrm{Ca}(\mathrm{mg})$ & & $200 \cdot 6$ & 93.6 & $250 \cdot 2$ & 99.7 & 0.000 & $226 \cdot 5$ & 99.8 \\
\hline$P(m g)$ & & $867 \cdot 4$ & 184.9 & 977.2 & $166 \cdot 2$ & 0.000 & $924 \cdot 7$ & 183.5 \\
\hline Vitamin $D(\mu \mathrm{g})$ & & 1.5 & 1.3 & $2 \cdot 8$ & 1.4 & 0.000 & $2 \cdot 2$ & 1.5 \\
\hline
\end{tabular}

$\mathrm{CHO}$, carbohydrate; LSES, lower socioeconomic strata; SI, suggested intake; USES, upper socioeconomic strata

* As tested by independent sample $t$-test (two-tailed) of the difference between the means of LSES and USES subjects.

was higher in USES as compared to LSES diets but no significant association was found with serum $25(\mathrm{OH}) \mathrm{D}$ levels $(r 0 \cdot 074, P=0 \cdot 137)$.

\section{Discussion}

The consensus has been that most children and adolescents should be able to synthesize sufficient vitamin $\mathrm{D}$ by brief exposure to sunlight and that only children living in northern or southern latitudes may require supplementation with vitamin $\mathrm{D}^{23,24}$. Examination of the recent evidence leads to different conclusions. Indeed, $80 \%$ of children and adolescents had insufficient vitamin D levels $(25(\mathrm{OH}) \mathrm{D}$ $<50 \mathrm{nmol} / \mathrm{l}$ ) in the winter in four studies conducted in Spain $^{25}$, Finland ${ }^{4}$, France ${ }^{26}$ and Turkey ${ }^{27}$. Although it is expected that children of different genders and socioeconomic backgrounds would have different lifestyles (exercise, sunlight exposure and nutrition), the few studies evaluating vitamin D status in children and adolescents have not systematically examined the impact of socioeconomic status and lifestyle on vitamin D levels. However, some studies have suggested that dietary factors possibly play only a minor role in the causation of hypovitaminosis $\mathrm{D}^{28,29}$. In India, similar to other Middle Eastern and some European countries, there are no governmental regulations mandating vitamin $\mathrm{D}$ fortification of food products. The main source of vitamin D is, therefore, through skin synthesis in response to sun exposure. Information about vitamin D status in healthy schoolgirls from a sun-drenched country like India is scarce. Furthermore, its association with nutrition and lifestyle has not been objectively studied in detail. Hence, the current study was planned to assess the same in schoolgirls in Delhi.
Endemic prevalence of clinical and biochemical hypovitaminosis was seen in healthy schoolgirls in Delhi. The present finding is in keeping with reports from European countries ${ }^{5,25}$, the USA ${ }^{8}$, a sun-rich country like Lebanon ${ }^{6}$ and India ${ }^{10}$. The present study found that USES subjects had significantly high serum $\mathrm{Ca}$ but low 25(OH)D levels. The negative correlation between vitamin D levels and PTH was expected, given the physiologic relation between vitamin $\mathrm{D}$ status and $\mathrm{PTH}^{26}$.

As expected, a gross difference was found in the nutritional status of the girls from two different socioeconomic backgrounds. USES girls were significantly taller and heavier than LSES counterparts. LSES had significantly lower energy, protein, $\mathrm{Ca}$ and higher carbohydrate, dietary fibre and phytate intake with regard to Indian Council of Medical Research recommendations and dietary suggestions ${ }^{19}$. The energy intake of the entire cohort of girls was significantly lower than the RDA matched for age as also reported by other researchers ${ }^{21,30,31}$. A significant disparity was seen in the consumption pattern of certain food groups with costlier foods like dairy foods, animal foods, fruits and vegetables being predominant in USES diets and cereals constituting the major bulk of the LSES diets. Across all age groups, mean $\mathrm{Ca}$ intake of USES was higher than LSES subjects and even higher than the RDA. While Ca intakes of younger LSES children met the RDA, as girls entered puberty (10 years onwards), $\mathrm{Ca}$ intakes were significantly lower than the RDA. This could be attributed to decrease in milk intake, which has also been reflected in previous Indian and international studies ${ }^{32-34}$, which showed that $\mathrm{Ca}$ intakes declined among females at the preadolescent-adolescent period ${ }^{35}$. 
We evaluated the possible causative factors for low vitamin D status in the present study population. Obese people have lower basal 25(OH)D and higher serum PTH concentrations than do non-obese persons. Even in individuals with normal BMI, serum 25(OH)D levels decrease with increasing percentage of body fat ${ }^{36,37}$. Wortsman et al. ${ }^{38}$ reported that vitamin $\mathrm{D}$ deficiency is probably due to decreased bioavailability of vitamin $\mathrm{D}_{3}$ from cutaneous and dietary sources because of its deposition in body fat compartments. While we have not measured percentage of body fat, the significant difference in BMI between the LSES and USES subjects suggest that body fat percentage may be higher in USES. This could possibly contribute to the deficiency in serum $25(\mathrm{OH}) \mathrm{D}$ levels between the two groups.

Among the dietary variables studied, a negative correlation of serum Ca was seen with phytate and fibre intake. Dietary fibre and phytate are associated with a reduction in the bioavailability of $\mathrm{Ca}$. North Indian diets are traditionally high in fibre and phytate since the staple cereal is whole wheat flour. However, such a correlation has not been consistently reported. Hu et al. ${ }^{39}$, Tandon et al. ${ }^{12}$ and Harinarayan et al. ${ }^{40}$ reported findings similar to the present findings, while Heaney ${ }^{41}$ found no such correlation.

It is pertinent to point out that there are no food products with adequate vitamin D fortification in India and none of the cooking mediums used in meal preparations in Indian homes are fortified with vitamin D. Indian diets, being predominantly vegetarian, are not rich in vitamin D. In the present study too, $50 \%$ of the whole cohort was vegetarian and even among the others frequency of consumption of eggs, fish and chicken was at the most one to two times per week. Since no estimates of vitamin D content of Indian foods have been provided by Indian Council of Medical Research ${ }^{19}$, the dietary vitamin D intakes were based on US Department of Agriculture data ${ }^{20}$. While dietary vitamin D intakes were higher in USES subjects, no significant association was found between dietary vitamin $\mathrm{D}$ and serum $25(\mathrm{OH}) \mathrm{D}$ as also reported by other investigators ${ }^{42,43}$. The contribution from sunlight was not taken into consideration for estimating vitamin D intakes.

Other possible determinants of low vitamin D status could be low sunshine exposure which can be explained by lower body surface area exposed, higher usage of sunscreen, less time spent on outdoor physical activity and greater indulgence in indoor activities like watching television, computer gaming, indoor tuition and other recreational activities among USES girls. This is in keeping with the fact that the main source of vitamin $\mathrm{D}$ is that produced by the action of solar UV B radiation acting on 7-dehydrocholesterol in skin; only small amounts are obtained from dietary sources. Avoidance of exposure to sunshine for cosmetic beliefs (usage of sunscreen creams) and style of dress has previously been reported as a risk factor for vitamin D deficiency in other countries ${ }^{27,43}$. A study by El-Hajj Fuleihan et al. $^{6}$ on healthy schoolchildren also reported low sun exposure, dress code and BMI as significant predictors of vitamin D levels. The observations indicate that clothing that covers from head to toe, application of sunscreen creams and girls from affluent society remaining indoors with low physical activity in spite of better nutrient intake in terms of dietary $\mathrm{Ca}$ and vitamin $\mathrm{D}$ intake presents a major problem in terms of vitamin $\mathrm{D}$ synthesis.
Recent nutritional guidelines targeted to children and adolescents to improve bone health have mainly stressed the importance of $\mathrm{Ca}$ and exercise. They have either omitted vitamin $\mathrm{D}$ or proposed that vitamin $\mathrm{D}$ supplementation is usually not necessary ${ }^{24,44}$. Evidence from the presnt study and others ${ }^{4,25,26}$ calls for a reconsideration of such a strategy.

\section{Conclusion}

Even in a sunny country like India, endemic prevalence of vitamin D insufficiency was seen in the whole cohort of apparently healthy Delhi schoolgirls with the prevalence being significantly higher among the USES girls even though they had better nutritional status. On the contrary, daily sun exposure (LSES $45 \mathrm{~min}$, USES $25 \mathrm{~min}, P=0.003$ ) and percentage of body surface area exposed $(28 \mathrm{v} .15 \%$, $P=0 \cdot 014)$ was significantly higher in LSES girls. A significant correlation between serum $25(\mathrm{OH}) \mathrm{D}$ and estimated sun exposure $(r 0 \cdot 185, P=0.001)$ and percentage of body surface area exposed $(r 0.146, P=0.004)$ was seen. The present observations suggest that lifestyle factors in terms of daily sun exposure, outdoor physical activity and percentage of body surface area exposed may contribute significantly to the optimal vitamin D status of apparently healthy school subjects. Hence, in the absence of availability of vitamin D-fortified food products in India, diet alone appears to have an insignificant role in the causation of vitamin D insufficiency.

\section{Acknowledgements}

Seema Puri and Raman K. Marwaha are to be considered as joint first authors. The study was supported in part by research grants from the Institute of Nuclear Medicine and Allied Sciences (INMAS), New Delhi. The contributions of the authors are as follows: Seema Puri and Raman K. Marwaha, design of the study, collection and analysis of data, and writing of the manuscript; Neha Agarwal, collection and analysis of data and writing of the manuscript; Nikhil Tandon, design of the study, analysis of data and writing of the manuscript; Rashmi Agarwal, D. H. K. Reddy and Khushi Grewal, collection of data; and Satveer Singh, laboratory assays.

\section{References}

1. Cadogan J, Blumsohn A, Barker ME \& Eastell R (1998) A longitudinal study of bone gain in pubertal girls: anthropometric and biochemical correlates. J Bone Miner Res 13, 1602-1612.

2. Whiting SJ \& Calvo MS (2005) Vitamin D insufficiency: a significant risk factor in chronic diseases and potential disease-specific biomarkers of vitamin D sufficiency. J Nutr 135, $301-303$.

3. Peterlik M \& Cross HS (2005) Vitamin D and calcium deficits predispose for multiple chronic diseases. Eur J Clin Invest 35, 290-304.

4. Lehtonen-Veromaa M, Mottonen T, Irjala K, Karkkainen M, Lamberg-Allardt C, Hakola P \& Vikari J (1999) Vitamin D intake is low and hypovitaminosis D common in healthy 9- to 15-year-old Finnish girls. Eur J Clin Nutr 53, 746-751. 
5. Outila Ta, Karkkainen MU \& Lamberg-Allardt CJ (2001) Vitamin D status affects serum parathyroid hormone concentrations during winter in female adolescents: associations with forearm bone mineral density. Am J Clin Nutr 74, 206-210.

6. El-Hajj Fuleihan G, Nabulsi M, Choucair M, Salamoun M, Hajj Shahine C, Kizirian A \& Tannous R (2001) Hypovitaminosis D in healthy schoolchildren. Pediatrics 107, 1-7.

7. Looker AC, Dawson-Hughes B, Calvo MS, Gunter EW \& Sahyoun NR (2002) Serum 25- hydroxyvitamin D status of adolescents and adults in two seasonal subpopulations from NHANES III. Bone 30, 771-777.

8. Gordon CM, De Peter KC, Feldman HA, Grace E \& Emans SJ (2004) Prevalence of vitamin D deficiency among healthy adolescents. Arch Pediatr Adolesc Med 158, 531-537.

9. Rajakumar K, Fernsttrom JD, Janosky JE \& Greenspan SL (2005) Vitamin D insufficiency in preadolescent African-American children. Clin Pediatr 44, 683-692.

10. Marwaha RK, Tandon N, Reddy DHK, Aggarwal R, Singh R, Sawhney RC, Saluja B, Ganie MA \& Singh S (2005) Vitamin $\mathrm{D}$ and bone mineral density status of healthy school children in northern India. Am J Clin Nutr 82, 477-482.

11. Goswami R, Gupta N, Goswami D, Marwaha RK, Tandon N \& Kochupillai N (2000) Prevalence and significance of low 25-hydroxyvitamin D concentrations in healthy subjects in Delhi. Am J Clin Nutr 72, 472-475.

12. Tandon N, Marwaha RK, Kalra S, Gupta N, Dudha A \& Kochupillai N (2003) Bone mineral parameters in healthy young Indian adults with optimal vitamin D availability. Nat Med J India 16, 298-301.

13. Cole TJ, Bellizzi MC, Flegal KM \& Dietz WH (2000) Establishing a standard definition for child overweight and obesity worldwide: international survey. Br Med J 320, 1240-1243.

14. Solomon L, Warwick D \& Nayagam S (2001) Apley's System of Orthopedics and Fractures, 8th ed. pp. 449-484, London: Arnold.

15. Portale AA (1997) Blood calcium, phosphorus and magnesium. In Primer on the Metabolic Bone Diseases and Disorders of Mineral Metabolism, 2nd ed., pp. 87-90 [MJ Favus, editor]. New York: Raven Press.

16. Lips P (2001) Vitamin D deficiency and secondary hyperparathyroidism in the elderly: consequences for bone loss and fractures and therapeutic implications. Endocr Rev 22, 477-501.

17. Khanna K, Gupta S, Seth R, Mahana R \& Rekhi T (1998) The Art and Science of Cooking, 3rd ed. New Delhi: Phoenix Publishing House.

18. Gopalan C, Ramasastry BV \& Balasubramaniam SC (2001) Nutritive Value of Indian Foods. Hyderabad: Indian Council of Medical Research.

19. Indian Council of Medical Research (2004) Nutrient Requirements and Recommended Dietary Allowances for Indians. New Delhi: Indian Council of Medical Research.

20. United States Department of Agriculture (1999) Provisional Table on the Vitamin D Content of Foods. HNIS/PT-108. Washington, DC: Human Nutrition Information Service.

21. Chugh R \& Puri S (2001) Affluent adolescent girls of Delhi: eating and weight concerns. Br J Nutr 86, 535-542.

22. Tyler M (2004) Burns. In Bailey and Love's Short Practice of Surgery, 24th ed., pp.266-278 [CV Mann, RCG Russel and NS Williams, editors]. London: Chapman and Hall.

23. Oliveri MB, Ladizesky M, Mautalen CA, Alonso A \& Martinez L (1993) Seasonal variations of 25 hydroxyvitamin D and parathyroid hormone in Ushuai (Argentina), the southernmost city of the world. Bone Miner Res 20, 99-108.

24. Weaver CM, Peacock M \& Johnston CC (1999) Adolescent nutrition in the prevention of postmenopausal osteoporosis. J Clin Endocrinol Metab 84, 1839-1843.
25. Docio S, Riancho JA, Perez A, Olmos JM, Amado JA \& Gonzallez-Macias J (1998) Seasonal deficiency of vitamin D in children: a potential target for osteoporosis preventing strategies. J Bone Miner Res 13, 544-548.

26. Guillemant J, Taupin P, Le HT, Taright N, Allemandou A, Peres G \& Guillemant S (1999) Vitamin D status during puberty in French healthy male adolescents. Osteoporos Int 10, 222-225.

27. Hatun S, Islam O, Cizmecioglu F, Kara B, Babaoglu K, Berk F \& Gokalp AS (2005) Sub clinical vitamin D deficiency is increased in adolescent girls who wear concealing clothing. Am Soc Nutr Sci 135, 218-222.

28. Stephens WP, Klimiuk PS, Warrington S \& Taylor JL (1982) Observations on the dietary practices of Asians in the United Kingdom. Hum Nutr Appl Nutr 36, 438-444.

29. Solanki T, Hyatt RH, Kemm JR, Hughes EA \& Cowan RA (1995) Are elderly Asians in Britain at a high risk of vitamin D deficiency and osteomalacia? Age Ageing 24, 103-107.

30. Chaturvedi S, Kapil U, Gnanasekaran N, Sachdev HP, Pandey RM \& Bhanti T (1996) Nutrient intake amongst adolescent girls belonging to poor socioeconomic group of rural area of Rajasthan. Indian Pediatr 33, 197-201.

31. Sharma AK, Shukla D \& Kannan AT (2005) Calorie and protein intake and its determinants among adolescent school girls in Delhi. Indian J Comm Med 30, 8-10.

32. Fleming KH \& Heimbach JT (1994) Consumption of calcium in the U.S.: food sources and intake levels. $J$ Nutr 124, S1426-S1430.

33. Nagi M, Chawla S \& Sharma S (1995) A study on the nutritional status of adolescent girls. Plant Foods Hum Nutr 47, 201-209.

34. Khader V (1996) Food intake and nutrient adequacy of rural population of Guntur district (Andhra Pradesh). Indian J Med Sci 50, 34-42.

35. Jasminka ZI, Mario S, Thomas H, Baoshe AN \& Velimir Matkovic (1998) Relation of nutrition, body composition and physical activity to skeletal development: a cross-sectional study in preadolescent females. Am J Coll Nutr 17, 136-147.

36. Arunabh S, Pollack S, Yeh J \& Aloia JF (2003) Body fat content and 25 hydroxy vitamin D levels in healthy women. $J$ Clin Endocrinol Metab 88, 137-161.

37. Parikh SJ, Edelman M, Gabriel I, Uwaifo, Freedman RJ, Janneh MS, Reynolds J \& Yanovski JA (2004) The relationship between obesity and serum 1,25-dihydroxy vitamin D concentration in healthy adults. $J$ Clin Endocrinol Metab 89, $1196-1199$.

38. Wortsman J, Matsuoka LY, Chen TC, Lu Z \& Holick MF (2000) Decreased bioavailability of vitamin D in obesity. Am J Clin Nutr 72, 690-693.

39. Hu JF, Zhao XH, Jia JB, Parpia B \& Campbell TC (1993) Dietary calcium and bone density among middle-aged and elderly women in China. Am J Clin Nutr 58, 219-227.

40. Harinarayan CV, Ramalakshmi T \& Venkatprasad U (2004) High prevalence of low dietary calcium and low vitamin D status in healthy south Indians. Asia Pac J Clin Nutr 13, 359-364.

41. Heaney RP (1986) Calcium, bone health and osteoporosis. In Bone and Mineral Research, pp. 255-301 [WA Peck, editor]. Amsterdam: Elsevier Science Publishers.

42. Gannage-Yared MH, Chemali R, Yaacoub N \& Halaby G (2000) Hypovitaminosis D in a sunny country: relation to lifestyle and bone markers. Bone Miner Res 15, 1856-1862.

43. Das G, Crocombe S, McGrath M, Berry JL \& Mughal MZ (2006) Hypovitaminosis D among healthy adolescent girls attending an inner city school. Arch Dis Child 91, 569-572.

44. Bachrach LK (2000) Making an impact on pediatric bone health. J Pediatr 136, 137-139. 